\title{
The Influence of Customer Knowledge on CRM Performance of Malaysian ICT Companies: A Structural Equation Modeling Approach
}

\author{
Hadi Nejatian, Ilham Sentosa \& Shishi Kumar Piaralal \\ Limkokwing University of Creative Technology \\ 63000 Cyberjaya, Selangor Darul Ehsan, Malaysia \\ E-mail: dr.ilhamsentosa@limkokwing.edu.my
}

Abdul Manaf Bohari

UUM College of Business, Universiti Utara Malaysia

315 Main Office (FPP Building), 06010 UUM Sintok, Kedah, Malaysia

Tel: 60-19-424-3648Ｅ-mail: abdmanaf.bohari@yahoo.com; manafdr@uum.edu.my

Received: October 27, 2010 Accepted: December 16, $2010 \quad$ doi:10.5539/ijbm.v6n7p181

\begin{abstract}
The business environment is transforming from product-centric to customer-centric. CRM as a customer-oriented business approach is considered as one of the powerful capabilities in organizations which help them to transform themselves to a customer-centric environment. The objective of the studies to configure the constructs of customer knowledge and CRM performance among 201 ICT companies in Malaysia. This study also examines the influence of customer knowledge as exogenous variable on CRM performance as endogenous variable as hypothesized. Using structural equation modeling (SEM) analysis method, the results confirmed knowledge for customer, knowledge from customer and knowledge about customer as constructs of customer knowledge. Financial, customer, internal process and innovation perspective also confirmed as constructs of CRM performance. The fundamental contribution of this study is determination of the significant interaction effect between customer knowledge and CRM performance constructs in the re-specified model of structural equation modeling (SEM). The utilization of CRM is directly related with increase in customer knowledge, which in turn has positive effect on customer satisfaction. By using knowledge management companies can improve their relationship with their valuable customers to create loyal customers and obtain competitive advantage.
\end{abstract}

Keywords: Customer knowledge, CRM performance, Structural equation modeling

\section{Introduction}

Today, firms are considering their customers as their most important assets (Croteau and Li, 2003), therefore they are transferring their business strategies from product-centric to customer-centric (Chen and $\mathrm{Su}, 2006$; Kotler, 2003).According to Park and Kim (2003); organizations are focusing more on acquiring and maintaining share of their customers rather than their markets' and by adopting customer-centric strategies, they demonstrate their insight on the importance of managing relationships with customers (Mithas et al.,2005). Organizations recognize customer knowledge as one of the major contributors of increase in their value and therefore they review their Customer Relationship Management (CRM) initiatives (Croteau and Li, 2003) to use in-depth and integrated customer knowledge for creating collective relationships with their customers (Boulding et al., 2005; Croteau and Li, 2003; Parvatiyar and Sheth, 2001). With arrival of knowledge-economy those organizations which successfully recognize, build and enhance their knowledge capabilities will be more successful and are considered as knowledge-enabled organizations (Rowley, 1999). These organizations segment their markets not only based on their products and services but also based on the amount of knowledge which they can learn from their customers (Zack, 2003).

Since the markets are becoming more and more complex and complicated, customers' demands for having products with lower price and better quality increase (Jutla et al., 2001). Meanwhile organizations try to find answers for questions like: who are their current customers, who and where their potential customers are, what benefits their customers are expecting from them and What are their customers' preferences, needs and problems (Annabi and Murillo, 2002; Rowley, 2002). Therefore for being able to compete in this competitive business environment, organizations are trying to have access to newer type of knowledge and capabilities (Jutla et al., 2001). Along with this competitive transition to a knowledge intensive environment, firms are becoming more dependent on detailed knowledge of their customers for improving their CRM objectives and finally their 
long-term business success (Bang et al., 2005; Bose and Sugumaran, 2003).As the result, firms are transforming their CRM from a transaction based system to a more knowledge intensive and analytical oriented system.

Through this transformation, organizations can maintain and improve their relationship with their customers throughout the customer lifetime cycle but this requires capabilities that enable them to follow and examine customers' activities and responses over time. They can obtain required capabilities by use of knowledge derived from CRM operations and other enterprise systems such as Knowledge Management (KM) system (Bose and Sugumaran, 2003). Although knowledge discovery in customer-centric approach companies is an important factor, but only few companies can manage this discovered knowledge in a systematic style and make this strategy more effective which provides them more economic value (Bang et al., 2005; Smith and McKeen, 2005; Zack, 2003). With help of CRM and its related technologies, organizations are able to gather, analyze and transfer customer information more easily, but they are not capable of transforming information in to knowledge. It is mainly because of relatedness of knowledge to individuals and group of them. Therefore organizations need to integrate customer knowledge in to their processes and procedures for bringing more value to their customers and themselves (Halinen and Rollins, 2005). This Integration helps organizations to have a successful CRM development and when they achieve a higher level of integration among their different functional areas, they will have a higher overall performance along with higher level of match between what their customers demand and what they offer (Campbell, 2001).

Despite the many studies that have been done, particularly in west (Bose and Sugumaran, 2003; Brenner et al., 2005; Campbell, 2001; Gibbert et al., 2002; Stefanou et al., 2003), to examine the relationship between Knowledge Management (KM) and Customer Relationship Management (CRM), none of them are comprehensive enough to capture all the factors into one single framework. According to Bose and Sugumaran (2003), true CRM could be achieved only through integration of KM with it which as the result improves business processes and allows firms to have a good evaluation on their customer's level of 'satisfaction, profitability and loyalty'. They also pinpoint the lack of a simple and general framework for integration of CRM functionalities with knowledge management capabilities (Bose and Sugumaran, 2003).

Today, the current challenge for organizations is to develop an integrated CRM platform. This platform enables organizations to collect relevant data about customers from existing customer interfaces. Although firms have access to huge amount of information about their customers like their behavioral actions, they still know little about how to manage this knowledge and use the best out of it (Campbell, 2001). Bang et al. (2005) acknowledges that successful CRM requires deep knowledge of customer (Knowledge Management), but the ways that these two types of technology fit in together needs research. Moreover, previous studies trying to link $\mathrm{KM}$ and CRM have been limited in scope and the results been affected by often methodological limitations or errors. Many of the previous studies have used qualitative methods (i.e. case studies, literature review) (for example, see Gibbert et al., 2002; Brenner et al., 2005; Campbell, 2001; Halinen and Rollins, 2005; Gao and Li, 2006) to conclude their research findings and some other few studies have used conclusive statistics (for example see, Stefanou et al., 2003). Therefore, in order to bridge the gap and provide organizations with assistance in dealing with management perspectives of KM's effect on CRM performance, this paper proposes a set of KM critical factors and develops a proposed model to show the relationship between KM critical factors and CRM.

\section{Review of Literature}

\subsection{Knowledge Management and CRM Association}

The goal of knowledge management is to build core competencies based on strategic business knowledge. Therefore, the related knowledge processes within organization should also be directed toward market oriented factors like customer needs, preferences and other external elements, in order to prevent core rigidity. In the other words, knowledge management should consider and integrate both strategic business areas (market oriented view) and organizational resources and competencies (resource based view) (Maier \& Remus, 2001).

Meantime, another underpinning theory for KM and CRM association which is originated from marketing literature is market orientation theory. Market orientation theory is a philosophy which puts its attention toward firm's resources regarding acquisition, collection, examination, distribution and respond to information from customers and competitors which finally leads to creation of more value for customers (Mitussis, O'Malley, \& Patterson, 2006; Richard, 2008).

According to literature market orientation consists of four fundamental attributes or dimensions: (a) customer orientation, (b) competitor orientation, (c) interfunctional coordination, and (d) profit orientation (Kohli \& Jaworski, 1990; Richard, 2008). Among all four dimensions, customer orientation has received the most amount of attention from researchers. Customer orientation describes the firms' focus on their customers through acquisition of capabilities to identify and respond their customer needs and requirements (Richard, 2008). It can be defined as obtaining clear insight on customers' ongoing needs, meeting their expectations and acquire their satisfaction, providing value for them constantly and commit to their requirements and feedbacks (Richard, 2008). 
Moreover, the study shows that market orientation has positive effect on customer satisfaction in which as a result increases customer retention and business profitability (Richard, 2008; Singh \& Ranchod, 2004). In addition, within the context of CRM market orientation can be used to describe the parameters related to KM and CRM association such as collection of data, analysis of data and distributing of information and intelligence for addressing customer satisfaction (Kohli et al., 1993; Richard, 2008).

\subsection{CRM Performance}

Although the demand for transformation of companies from product-centric to customer-centric is growing fast but for measuring the performance of CRM, as result of KM integration, still, there is no any well accepted set of metrics or a measurement system (Brenner et al., 2005; Payne and Frow, 2005). According Grabner-Kraeutera et al. (2007), the absence of "holistic framework" for determining success metrics as well as insufficient implementation of performance measurement processes are important reasons for failure of many CRM initiatives. Llamas and Sule (2004), confirm that by mentioning the main reasons for failure in establishment of a standard framework for performance measurement in the field of marketing. They state reasons such as, the short term characteristics of current performance metrics, their restricted diagnostic power and finally the absence of a general agreement on the amount of measures and succeeding problems in performing comparisons (Llamas and Sule, 2004).

Based on reviewed literature there are different methods and categorizations for CRM performance, such as financial versus non-financial; one-dimensional versus multi-criteria; hard versus soft; tangible versus intangible (Chi et al., 2004; Kim et al., 2003; Llamas and Sule, 2004; Payne and Frow, 2005). The most common categorizations of CRM performance are regarding to financial and non-financial and also tangible and intangible success measures. In terms of financial or tangible measures, measures such as net profit, net sales, reduced costs, market share, customer share and cash flow (Kim et al., 2003; Llamas and Sule, 2004; Pine et al, 1995) can be considered. Measures such as customer satisfaction, customer loyalty, increased customer lifetime value, service and quality improvement, innovation and competitiveness are considered as nonfinancial or intangible measures (Chi et al., 2004; Kim et al., 2003; Llamas and Sule, 2004; Payne and Frow, 2005). Although, financial and nonfinancial measures may seem to be in opposition of each other, but further studies indicate the strong relationship between nonfinancial measures such as customer satisfaction and customer retention and companies' profitability as financial measures (Llamas and Sule, 2004).

Beside different categorizations of CRM performance and outcomes, literature also shows different methods of measuring CRM performance. In their model for evaluating the performance of CRM, Kim et al. (2003), used the adapted model of Balanced Scored Card. They substituted factors such as customer knowledge, customer interaction, customer value and customer satisfaction with the original elements included in the traditional Balanced Scored Card (Kim et al., 2003; Llamas and Sule, 2004). Payne and Frow (2005), based on their study, state different CRM performance measures such as profit, revenues, customer retention, customer satisfaction and combination of customer retention and customer satisfaction, which have been adopted by previous researchers. Meantime they divide the CRM assessment process, as part of their "strategic framework for CRM", in to two components called "shareholder results" and "performance monitoring". The first one provides the overall view of relationships and consideration of building customer and employee value as ultimate objective of CRM and the latter provides more specific view on CRM measures and performance indicators (Payne and Frow, 2005).

The improvement in customer knowledge has impact on relationship between CRM and customer satisfaction (Mithas et al., 2005). Measuring customer satisfaction offers an immediate, meaningful, and objective feedback about customer preferences and expectations (Kim et al., 2003). Customer life time value is another important performance measure for CRM. According to Pine et al. (1995), "Lifetime value is the sum of the future stream of profits and other benefits attributable to all purchases and transactions with an individual customer, discounted back to its present value". Thus, if company could achieve to keep its customers longer, it will be able to receive more profit from them due to factors such as: increase in purchase, cost reduction in operations, referrals and word of mouth, premium prices and cost reduction in customer acquisition processes and activities. But some customers will have a higher lifetime value due to the knowledge that they provide to company, because this knowledge gives the company the new skills and capabilities which can be used for other customers as well. Pine et al. (1995), also describe customer share as one of performance measures which is the company's share on each of its customers total business trade. The company can calculate its customer share through understanding of what customer wants to buy from competitor and what she/he might be willing to buy from the company.

\subsection{Financial Perspective}

According to Kim et al. (2003), the financial perspective represents the tangible and intangible benefits obtained from management of relationship with customers. Such benefits and values can be obtained by increasing the amount of customer relationship's lifetime with firm or in other words increasing customer lifetime value. Establishing and managing successful relationship with customers also enhances customers' commitment on having more business interactions with firm which as a result will lead to more customer loyalty (Croteau and 
Li,2003; Kim et al.2003; Stefanou et al., 2004).

Furthermore, firms can also be benefitted from some tangible results such as cost reductions in regarding the customer retention and sales activities. In fact, CRM can help organizations to use customer knowledge and improve their customer acquisition procedures and reduce the amount of costs related to maintaining and retaining of customers in which will lead to more business gain and profit (Croteau and Li,2003; Kim et al.2003; Stefanou et al., 2004).

\subsection{Customer Perspective}

Customer satisfaction is considered as an ultimate outcome of CRM. It is difficult for firms to measure customer satisfaction because it is hard to quantify the satisfaction level of customers. Customer satisfaction represents a modern approach for quality in enterprises and organizations, and serves as the development of a truly customer-focused management and culture within an organization. Measuring customer satisfaction offers an immediate, meaningful, and objective feedback about customer preferences and expectations (Kim et al., 2003). In fact, by identifying how supplied services and products are fitting or surpassing customers' expectations, firms are able to measure the level of customer satisfaction as a result of CRM. Moreover, there are also other measures which can be used as outcomes of CRM from customer perspective. For instance, by measuring the rate of repeat purchases or the level of cross-selling revenues firms can assess CRM performance from customer perspective (Grabner et al., 2007; Kim et al., 2003; Stefanou et al., 2004).

\subsection{Internal Process Perspective}

Internal process perspective focuses on how well the organizations are managed to make the most effective use of CRM at operational level. In fact, through internal process perspective the organizations can reflect the efficiency in supporting CRM including improvement in customer segmentation, communication with customers, productivity and efficiency in activities related to sales, marketing, customer support and etc (Chang and Hsiao, 2005; Kim et al.2003; Payne and Frow, 2005). Besides, measures such as effective targeted customer relationship programs and marketing campaigns, shorter organizational sales, marketing, customer support and service cycle and finally, the provision of added value for customer through product customization, additional information provision and quality enhancements (Croteau and Li,2003; Kim et al.2003; Payne and Frow, 2005; Stefanou et al., 2004).

\subsection{Innovation Perspective}

The innovation perspective represents understanding of customer needs and preferences and integrating them in to new and innovative products and services. Therefore continuous interaction with customers and obtaining customer knowledge are essential elements for meeting the needs of customers (Kim et al., 2003). In order to evaluate the performance of CRM from innovation perspective organizations can focus on measures such as improvements on level of understandings on customers and their needs, improvements in methods of product development, improvements in level of product and service quality and finally innovative customization or creation of new innovative products which reflects customers' needs and demands (Grabner et al., 2007; Kim et al., 2003; Stefanou et al., 2004).

In the business environment, which was previously driven by organizations' products offerings and now dominated by customer needs and preferences, knowledge of the customer is considered as an important organizational asset which can bring competitive advantage to organizations and help them to have a focused strategy upon their customers (Shanks and Tay, 2001). According to Park and Kim (2003), for having a long term relationship with customers, firms should have a continuous relationship with their customers along with provision of distinguished value for them. Thus this sustainable relationship is strongly dependent on customer knowledge, with support of information technology, organizations will manage customer knowledge to improve their relationship with their customers and hence achieving competitive advantage.

The definition and categorization of customer knowledge varies based on different research perspectives. One of the commonly accepted definitions of customer knowledge is from Feng and Tian (2005), originally defined by Gebert (2003) and Blosch (2000). They define customer knowledge as "the dynamic combination of experience, value and insight information which is needed, created and absorbed during the process of transaction and exchange between the customers and enterprise". Campbell (2001) defines customer knowledge as "organized and structured information about the customer as the result of systematic processing". According to Mithas et al., (2005) originally cited by Davenport and Klahr (1998), customer knowledge is considered a one of the complex types of knowledge. The reason is due to existence of different sources and channels which customer knowledge can be captured, its multiple contextual meanings and finally its dynamic nature which makes it to be changed fast.

The evolved concept of marketing, views customers as cocreators and coproducers which can be considered as form of value proposition (Bendapudi and Leone 2003; Prahalad and Ramaswamy 2004; Vargo and Lusch 2004; Payne and Frow, 2005). Therefore Companies should try to keep their customers as much as possible, especially those which are economically valuable and are called as "frequent purchasers". The more their customers get involved in learning relationship and transfer the knowledge of their desires and preferences to company, the 
more they become reluctant to redo this process with another company (Pine et al, 1995). Shanks and Tay (2001) acknowledge that organizations are increasing the utilization of customer knowledge in order to obtain competitive advantage. Having in-depth knowledge of customer behaviors will help organizations to focus on their target customers based on customers' evolving needs and experiences instead of customers' general characteristics, which finally increases the firms' products perceived value and switching cost (Mithas et al., 2005).In the other side, the shared customer knowledge could help employees to do cross-selling and predict the market demand which helps to leverage the competitive advantage more effectively (Mithas et al., 2005). But although capture of customers knowledge and information, provides a powerful competitive advantage to organizations but they should be aware that they cannot treat their customers as static individuals. They should know that the nature of relationship between customers and organizations is dynamic and like organizations which change throughout the time therefore customers also change which as the result their preferences, desires, lifestyles, conditions and interaction channels always evolve and change. Thus observation and monitoring of relationships with customers should be done constantly and thoroughly at all aspects (Blosch, 2000; Pine et al, 1995).

As mentioned above, there are different types of definitions and classifications for customer knowledge. Gibbert et al. (2002), have classified the customer knowledge, from organization's point of view, in to three types: knowledge for customers, knowledge about customers and knowledge from customers. The similar classification of customer knowledge has been made by scholars such as Brenner et al. (2005); Feng and Tian (2005); and Ye Naiyi (2002). In other classifications, Crie and Micheaux (2006) divide customer knowledge in to two types, "Behavioral" or Quantitative and "Attitudinal" or Qualitative. The behavioral knowledge is easy to obtain and they are basically quantitative by nature which contain customer's transactional relations with firm. On the other side, attitudinal knowledge is difficult to obtain because it deals with customer's state of mind but meanwhile it is an important factor for enhancement of customer knowledge because they are directly related to customer's thoughts and insights. For the purpose of this paper, the Gibbert et al. classification of customer knowledge, which is a commonly used classification, has been adopted.

Knowledge for Customers is unidirectional knowledge which is sent from organizations to support their customers and make customers to understand their offered products better (Gibbert et al.; 2002; Smith and McKeen, 2005). This knowledge could help organizations to sustain their customers by focusing on changing the customer's preferences and increases their demands' compatibility with the offered product which finally leads to purchase of product by customer (Feng and Tian, 2005). Moreover, Feng and Tian (2005) also note that the meaning of what they define as 'knowledge for customers' is different with the one which has been defined by Gebert and Blosch. They acknowledge that by mentioning the fact that: "The knowledge prepared for the customer is not necessarily the knowledge the customer needs".

Knowledge about customers is firm's comprehension on customer's background, desires and preference on product characteristics (Chen and $\mathrm{Su}, 2006$ ). Customers are interacting with organizations through multiple and different channels and based on the type of channel that they interact; organizations can segment their customers and also define their relationships with them. Moreover this can be done through acquired knowledge from channels which are derived from statistical information and historical data of customer's purchases or their interactions. This acquired knowledge is considered as organization's insight on each customer's demand and preference or organizations' knowledge about their customers (Blosch, 2000; Feng and Tian, 2005; Gibbert et al., 2002).

Knowledge from customers is the knowledge which resides in customers, and organizations should pay attention to this knowledge more than two other types (Paquette, 2006). This knowledge contains information that customers have about organization's products and services, its competitors' products and services, customers' inputs for product development and innovation, and their preferred channels of communication (Feng and Tian, 2005). Knowledge for customers is generated from data obtained through customers' direct complaints, needs and suggestions and helps organization to focus on correct market segments and adopt appropriate business strategies for their product development and marketing activities (Chen and Su, 2006; Park and Kim, 2003).

\section{Methodology}

Figure 1 proposes the hypothesized structural model for the study. It consists of customer knowledge as exogenous variables with three constructs: customer for knowledge, customer from knowledge and customer about knowledge. CRM performance as endogenous variables with four constructs: financial, customer, internal process and innovation perspective.

\section{Insert Figure 1 here \\ Insert Table 1 here}

Table 2 summarizes the operation definition of final latent variables used in this study. Afterwards, nine hypotheses (Table 1) are derived from the structural model for the study.

Insert Table 2 here 


\subsection{Sampling and Measurement}

A total of 201 ICT companies in Malaysia were requested to complete a questionnaire that contained measures of the constructs of concern. The questionnaires were distributed to the respondents by using purposive sampling method. The approach to testing the knowledge management and CRM performance constructs the hypothesized model and measures knowledge for customer ( 5 items), knowledge from customer (6 items) and knowledge about customer ( 7 items), financial perspective (6 items), customer perspective ( 3 items), internal process $(8$ items) and innovation perspective (5 items) were utilized based on past studies. All the questions use 5-Likert interval scales measurement (5 - strongly agree and 1- strongly disagree). There are also six demographic questions included in the instrument which use ordinal and nominal scale such as of MSC Status, job position, department, nature of business, years of operation and number of employees.

\subsection{Data Screening and Analysis}

The dataset were coded and saved into SPSS version 17.00 and analyzed using AMOS version 18.00. During the process of data screening for outliers, dataset were finalized due to Mahalanobis values more than the $\chi 2$ value $\left(\chi^{2}=72.06 ; \mathrm{n}=39, \mathrm{p}<.001\right)$ leaving a final 201 dataset to be analyzed. Several statistical validity tests and analysis were then conducted such as reliability test and composite reliability tests, validity tests using confirmatory factor analysis (CFA) for construct validity, discriminant validity for multicollinearity treatment, descriptive analysis, correlation and structural equation modeling analysis using AMOS 18.00 (SEM). The step in SEM analysis are $2^{\text {nd }}$ order analysis, measurement analysis, discriminant analysis, composite reliability analysis and direct impact analysis, testing the fit for the hypothesized structural model, generated model and revised model

\section{Results}

\subsection{Profiles of Respondents}

From Table 3 we can observe that the majority of the ICT companies have MSC status (70.1\%). In term of job position there were Executive (14.4\%), Senior Executive (25.4\%), Manager (45.3\%) and General Manager (14.9\%). It can also be observed that there were $18.9 \%$ respondents on Marketing/Sales department, Information Technology (18.4\%), Operation (9.5\%), Customer Service (13.9\%), Human Resource/Admin (13.9\%), Finance (5.5\%), Engineering (7\%), Research and Development (10\%), and Others (3\%). From the nature of business, there were Business Process Outsourcing (4\%), Communication/Networking (6.5\%), Consultancy/Professional Services (13.4\%), Creative Multimedia (12.4\%), Education/Training (5\%), Hardware Design (6\%), Internet Based Business (10.9\%), Network Security (2\%), Shared Services and Outsourcing (10.4\%), Software Development (22.4\%), and Support Services (7\%). Most of companies (48.3\%) have running their business less than 5 years, 6 to 10 years $(30.8 \%), 11$ to 15 years $(12.4 \%)$ and $8.5 \%$ companies running more than 16 years. From the number of employees we can observed that the majority company $(76.1 \%)$ has less than 50 employees, followed by 51 to $100(10 \%)$ and more than 10 employees (13.9\%). We believe that the above sample in term of MSC Status, Job Position, Department, Nature of Business, Years of Operation and Number of Employees produces moderately homogenous sample pool for this research.

\subsection{Descriptive Analysis of Variables}

The research framework consists of three exogenous of customer knowledge constructs and four constructs of CRM performance as endogenous variables (Table 4). Each construct shows Cronbach's alpha readings of acceptable values of above 0.60 (Nunnally, 1970). However, this variable is included in subsequent analysis since composite reliability calculated for subjective norms is 0.779 , thus conforming to Nunnally's standard.

\section{Insert Table 3 here \\ Insert Table 4 here}

From the confirmatory factor analysis result in Table 5, we observed that the factor loadings of all observed variables or items are adequate ranging from 0.626 to 0.933 . The factor loadings or regression estimates of latent to observed variable should be above 0.50 (Hair et al., 2006). This indicates that all the constructs conform to the construct and convergent validity test (Kamariah and Sentosa, 2008). The remaining numbers of items for each construct are as follows: Customer for knowledge ( 3 items), Customer from knowledge ( 3 items), Customer about knowledge (3 items), Financial perspective (4 items), Customer perspective (3 items), Internal process perspective ( 2 items), and Innovation perspective ( 3 items).

\section{Insert Table 5 here}

\subsection{Composite Reliability and Discriminant Validity of the Constructs}

Table 6 shows the result of the calculated composite reliability and variance extracted to support composite reliability of each construct (with error consideration) and discriminant validity of constructs respectively. The average variance extracted (AVE) measures the "amount of variance that is captured by the construct in relation to the amount of variance due to measurement error" (Fornell and Larcker 1981). The AVE can be interpreted as a measure of reliability for a construct and it is recommended that the AVE should be greater than 0.50 , which indicates that the construct captures more variance in the items than measurement error (Hair et al. 2006; Chin, 1998). According to Fornell \& Larcker (1981), AVE should be more than the correlation squared of the two 
constructs to support discriminant validity (compare Table 7 and Table 8). Each AVE value is more than correlation squared, thus discriminant validity is supported or multicollinearity is absent (Kamariah and Sentosa, 2008).

\section{Insert Table 6 here \\ Insert Table 7 here \\ Insert Table 8 here}

\subsection{Goodness of Fit Indices}

Confirmatory factor analysis was conducted on every construct and measurement models (see Table 9). All $2^{\text {nd }}$ order models and re-specified model produced a relatively good fit as indicated by the goodness of fit indices such as CMIN/df ratio $(<2)$; p-value $(>0.05)$; Goodness of Fit Index (GFI) of $>.95$; and root mean square error of approximation (RMSEA) of values less than .08 $(<.08)$. The measurement model has a good fit with the data based on assessment criteria such as $2^{\text {nd }}$ order analysis of customer knowledge and CRM performance, CMIN, DF, Ratio, P Value, GFI, RMSEA (Bagozzi \& Yi, 1988). Table 9 shows that the goodness of fit of generated and re-specified model is better compared to the hypothesized model. The goodness of fit of re-specified as the final hypothesized model confirmed the achievement of hypothesis 4.

\section{Insert Table 9 here}

\subsection{Results of Hypotheses Testing and Variance Explained (Square Multiple Correlation)}

Figure 2 show the significant of $2^{\text {nd }}$ order analysis of customer knowledge which confirmed knowledge for customer $(\beta=0.685 ; C R=9.266 ; p>0.000)$, knowledge from customer $(\beta=0.923 ; C R=9.006 ; p>0.000)$ and knowledge about customer $(\beta=0.640 ; C R=9.266 ; p>0.000)$ as constructs of customer knowledge. However, Figure 3 also confirmed the significant results of $2^{\text {nd }}$ order analysis of CRM performance which confirmed financial perspective $(\beta=0.746 ; C R=9.568 ; p>0.000)$, customer perspective $(\beta=0.819 ; C R=9.624 ; p>0.000)$, internal perspective $(\beta=0.883 ; C R=10.279 ; p>0.000)$ and innovation perspective $(\beta=0.755 ; C R=9.624 ; p>0.000)$ as the constructs.

Furthermore, Figure 2, Figure 3 and Table 10 confirmed the loading of the factors, thus hypotheses 1 and 2 were asserted. Table 10 and Figure 5 also show that customer knowledge and CRM performance has a direct positive significant influence on CRM performance $(\beta=0.584 ; C R=6.495 ; p>0.000)$, thus hypotheses 3 asserted and it could be deducted that CRM performance explains $34.1 \%$ of the variance in customer knowledge. The structural model output displayed in figure 5 shows that the model explained a substantial portion of the variance in all the endogenous variables (square multiple correlations).

\section{Insert Table 10 here \\ Insert Figure 2 here \\ Insert Figure 3 here}

\subsection{Generated Model}

\subsection{Revised Model}

In the re-specified model, researcher confirmed as the final model of the hypothesized model. The significant of the goodness of fit indexes confirmed the significance loading of measurement, the low level of common and unique error and shows the interaction among predictors on endogenous variable.Figure 5 depicts the structural path readings derived from the Structural Equation Modeling (SEM) analysis. The Goodness of Fit (GOF) of the structural model shows support according to the standard norms in structural equation GOF indices as presented in Table 9.

\section{Discussions}

\section{Insert Figure 5 here}

Our main concern in this study is to confirm the construct of customer knowledge and CRM performance. Consequently, we found knowledge for customer, knowledge from customer and knowledge about customer confirmed as construct of customer knowledge. Our findings are similar with many past findings (Garcia-Murillo \& Annabi (2002), Park \& Kim (2003), Smith \& McKeen (2005), Chen \& Su (2006), Feng \& Tian (2005), Park \& Kim (2003). Our study also found significant assertions for direct paths from customer knowledge on CRM performance. Hence, these findings substantiate the appropriateness of knowledge management in ICT industry By using knowledge management companies can improve their relationship with their valuable customers to create loyal customers and obtain competitive advantage (Paquette, 2006). Since knowledge management is responsible for acquiring and collecting the expertise and knowledge within organizations to promote innovation in organizations and meantime CRM is able to capture customer preferences, desires and above all, their knowledge; the integration of these two concepts provide tremendous amount of benefits to organizations 
(Massey et al., 2001; Nonaka, 1991; Quinn et al., 1996; Romano, 2000). Organizations can create new ideas and provide improved and new services by help of knowledge management and the knowledge originated from CRM (Chen and $\mathrm{Li}, 2006$ ). The acquired knowledge of customers is called customer knowledge which includes customers' preferences, desires, needs, buying behaviors and their insight on companies' products and services.

\section{Conclusions and Recommendations}

This research has found significant direct influence of customer knowledge on CRM performance of ICT companies in Malaysia. This study also confirmed the significant constructs of customer knowledge and CRM performance on the structural model. The construct has been tailored according to the Malaysian context. We believe that the model we have suggested could be useful for managerial research and practice of customer knowledge and CRM performance especially in the ICT industry for the improvement of knowledge management in Malaysia. Model of customer knowledge and CRM performance is also valid for knowledge management development in Malaysia.

We also suggest that this model should be implementing to focus more on the key role of the knowledge management improvement as usefulness of the service embedded in the technology industry. The business environment is changing from industrial to information environment and this transition includes the reassignment of core capabilities in organizations. CRM as a customer-oriented business approach is considered as one of the powerful capabilities in organization which help them to transform themselves to a customer centric environment but CRM utilization is directly related with increase in customer knowledge, which in turn has positive effect on customer satisfaction (Boulding et al., 2005).

The customer knowledge as an integral element of Knowledge Management and CRM relationship could help organizations to tailor their products and services and even the entire relationship with customers to increase customer satisfaction and finally economic profitability (Bose and Sugumaran, 2003; Boulding et al., 2005; Chen and Li, 2006; Mithas et al., 2005; Smith and McKeen, 2005). Thus, measuring the impact of Knowledge Management on CRM is a necessary action to demonstrate the results of Knowledge Management and CRM interaction. The outcomes of the interaction effect between Knowledge Management and CRM can be considered as both tangible and intangible. Measures such as net profit, net sales, and customer share are considered as tangible outcomes of CRM performance and as intangible ones, measures such as customer satisfaction, customer loyalty and increased customer lifetime value are considered as important intangible outcomes of CRM in perspective of relationship between Knowledge Management and CRM. Although there have been numerous amount of studies conducted on field of CRM performance, this research confirmed the fundamental finding as role model of CRM performance improvement using customer knowledge as predictors interactively in the structural model.

\section{References}

Anderson, J., \& Gerbing, D. (1988). Structural equation modeling in practice: A review and recommended two-step approach. Psychological Bulletin, 103(3), 411-423.

Bagozzi, R., \& Yi, Y. (1988). On the evaluation of structural equation models. Journal of the Academy of Marketing Science, 16, 74-94.

Ballantyne, D. (2004). Dialogue and its role in the development of relationship specific knowledge. Journal of Business \& Industrial Marketing, 19(2), 114 -123.

Bagozzi, R., \& Yi, Y. (1988). On the evaluation of structural equation models. Journal of the Academy of Marketing Science, 16, 74-94.

Blosch, M. (2000). Customer Knowledge. Journal of Knowledge and Process Management, 7(4), 265 - 268.

Boulding, W., Staelin, R., Ehret, M., \& Johnston, W.J. (2005). A customer relationship management roadmap what is known, potential pitfalls, and where to go. Journal of Marketing, 69, 155-166.

Bose, R., \& Sugumaran, V. (2003). Application of Knowledge Management Technology in Customer Relationship Management. Knowledge and Process Management, 10, 3 - 17.

Bueren, A., Ragnar S., Kolbe, L.M., \& Brenner, W. (2005). Improving performance of customer-processes with knowledge management. Business Process Management Journal, 11(5), 573-588.

Byrne, B. (2001). Structural Equation Modeling with AMOS Basic Concept Aplication and Programming: Lawrencen Erlbaum Associates.

Campbell, A. (2001). Achieving customer knowledge competencies: managing customer relationship management programs strategically. Proceedings of the 17th IMP Conference, September 9-11 2001. Oslo, Norway.

Cepeda-Carrion, G. (2006). Competitive advantage of knowledge management. Encyclopedia of Knowledge Management: Idea Group Inc.

Chen, Yarong \& Li, Ling. (2006). Deriving information from CRM for knowledge management: A note on a commercial bank. Systems Research and Behavioral Science, 26, 141-146. 
Chen, Yung-Hsin \& Su, Chao-Ton (2006). A Kano-CKM model for customer knowledge discovery. Total Quality Management \& Business Excellence, 17(5), 589 - 608.

Chong, Siong Choy. (2006). KM implementation and its influence on performance: Empirical evidence from Malaysian Multimedia Super Corridor (MSC) Companies. Journal of Information \& Knowledge Management, $5(1), 21-37$.

Crie, D., \& Andrea, M. (2006). From customer data to value: What is lacking in the information chain. The Journal of Database Marketing \& Customer Strategy Management, 13(4), 282-299.

Dous, M., Harald S., Lutz K., \& Walter B. (2005). Knowledge Management Capabilities in CRM: Making Knowledge For, From and About Customers Work. In the Proceeding of Eleventh Americas Conference on Information Systems, August 11-14, 2005, Omaha, NE, USA.

Feng, Tian-Xue \& Tian, Jin-Xia (2005). CKM and condition analysis of successful CKM implementation. In the Fourth International Conference on Machine Learning and Cybernetics, 18 - 21 August 2005, Guangzhou.

Fornell \& Larcker. (1981). Evaluating structural equation models with unobservable variables and measurement error. Journal of Marketing Research, 48, 39 - 50.

Garcia-Murillo, M \& Annabi, H. (2002). Customer knowledge management. Journal of the Operational Research Society, 53, 875 - 884.

Gibbert, M., Leibold, M., \& Probst, G. (2002). Five styles of customer knowledge management. European Management Journal, 20(5), 459-469.

Grabner-Kraeutera, Sonja, Gernot Moedritscherb, Martin Waigunyc \& Werner Mussnigb. (2007). Performance Monitoring of CRM Initiatives. In the 40th Annual Hawaii International Conference on System Sciences, January 3-6, 2007, Hawaii, USA.

Greve, S. Albers. (2006). Determinants of Performance in Customer Relationship Management: Assessing the Technology Usage - Performance Link. In the 39th Annual Hawaii International Conference on System Sciences Hawaii, 4-7 January 2006, Kauai, HI, USA.

Hair, J., Black, B. Babin, B., Anderson, R., \& Tatham, R. (2006). Multivariate Data Analysis (6 ${ }^{\text {th }}$ edition). Upper Saddle River, NJ: Prentice-Hall.

Kendrick, T., \& Fletcher, K. (2002). Addressing customer myopia: Strategic interactive marketing planning in a volatile business environment. Journal of Database Market, 9(3), 207-218.

Kim, J., Suh, E., \& Hwang, H. (2003). A model for evaluating the effectiveness of CRM using the balanced scorecard. Journal of Interactive Marketing, 17(2), 27-28.

Kohli A and Jaworski BJ. (1990). Market orientation: the construct, research propositions, and managerial implications. Journal of Marketing, 54, 1-18.

Jutla, D., Craig, J. \& Bodorik, P. (2001). Enabling and Measuring Electronic Customer Relationship Management Readiness. In the 34th Hawaii International Conference on System Sciences, January 3-6, 2001, Hawaii.

Kamariah, N.M., \& Sentosa, I. (2008). The Integration of Technology Acceptance Model and Technology of Puchasing Behavior (A Structural Equation Modeling Approach). The Proceeding Asia Pacific Conference on Management of Technology and Technology Entrepreneurship, October, 29, 2008, Melaka, Malaysia.

Garcia-Murillo \& Annabi, H. (2002). Customer knowledge management. Journal of the Operational Research Society, 53, 875-884.

Maier, R., and Remus, U. (2001). Towards a Framework for Knowledge Management Strategies: Process-Orientation as a New Strategic Starting Point," hicss, vol. 4, pp.4023, 34th Annual Hawaii International Conference on System Sciences (HICSS-34)-Volume 4, 2001.

Mitussis, D., O'Malley, L., and Patterson, M. (2006). Mapping the re-engagement of CRM with relationship marketing. European Journal of Marketing, 40(5/6), 572-589.

Nunnally, J.C. (1970). Introduction to Psychological Measurement. New York: McGraw-Hill.

Park, Chung-Hoon \& Kim, Young-Gul. (2003). A framework of dynamic CRM linking marketing with information strategy. Business Process Management Journal, 9(5), 652-671.

Payne, A., \& Frow, P. (2005). A strategic framework for customer relationship management. Journal of Marketing, 69(4), 167-176.

Piller, F.T., \& Moeslein, K. (2002). From Economies of Scale towards Economies of Customer Integration. In 15th Bled Electronic Commerce Conference e-Reality: Constructing the e-Economy, June 17-19, 2002, Bled, Slovenia.

Roscoe, D. (2001). Customer Knowledge Journey. Journal of Financial Services Marketing, 5(4), 314-316.

Rowley, J. (1999). What is knowledge management? Library Management, 20(8), 41-42(42). 
Rowley, J. (2002a). Eight questions for CKM in e-business. Journal of Knowledge Management, 6(5), 500-511. Rowley, J. (2002b). Reflections of Customer Knowledge Management in e-business. Qualitative Market Research: An International Journal, 5(4), 268-280

Richard, J. E. (2008). The Impact of Customer Relationship Management (CRM) Technology on Business-to-Business Customer Relationship". Unpublished academic dissertation, Victoria University of Wellington, New Zealand.

Singh, S., \& Ranchod, A. (2004). Market orientation and customer satisfaction: Evidence from British machine tool industry. Industrial Marketing Management, 33(2), 135-144.

Smith, Heather A., \& McKeen, James D. (2005). Developments in practice XVIII-Customer knowledge management: adding value for our customers. Communications of the Association for Information Systems, 16(36), 31-43.

Stefanou, C.J., Sarmaniotis C., \& Stafyla A. (2003). CRM and customer-centric knowledge management: An empirical research. Business Process Management Journal, 9, 617-634.

Tay, G., \& Shanks, E. (2001). The role of knowledge management in to a customer focused organization. In the 9th European Conference on Information Systems. Bled, Slovenia.

Table 1. Hypotheses Formulation

\begin{tabular}{|l|l|}
\hline H1a & Customer for knowledge confirm as construct of customer knowledge \\
\hline H1b & Customer from knowledge confirm as construct of customer knowledge \\
\hline H1c & Customer about knowledge confirm as construct of customer knowledge \\
\hline H2a & Financial perspective confirm as construct of CRM performance \\
\hline H2b & Customer perspective confirm as construct of CRM performance \\
\hline H2c & Internal process perspective confirm as construct of CRM performance \\
\hline H2d & Innovation perspective confirm as construct of CRM performance \\
\hline H3 & Customer knowledge has a direct positive significant influence on the CRM performance \\
\hline H4 & $\begin{array}{l}\text { Customer } \text { knowledge and CRM performance constructs have an interaction effect on significant structural } \\
\text { equation model }\end{array}$ \\
\hline
\end{tabular}

Table 2. Operational definition of Variables

\begin{tabular}{|c|c|c|c|}
\hline \multirow{3}{*}{$\begin{array}{l}\text { Customer } \\
\text { Knowledge }\end{array}$} & $\begin{array}{l}\text { Customer } \\
\text { For } \\
\text { Knowledge }\end{array}$ & $\begin{array}{l}\text { Unidirectional knowledge which is sent from organizations } \\
\text { to support their customers and make customers to } \\
\text { understand their offered products better. }\end{array}$ & $\begin{array}{l}\text { Feng \& Tian (2005), } \\
\text { Park \& Kim (2003) }\end{array}$ \\
\hline & $\begin{array}{l}\text { Customer } \\
\text { From } \\
\text { Knowledge }\end{array}$ & $\begin{array}{l}\text { The knowledge which resides in customers and } \\
\text { organizations should pay attention to this knowledge. }\end{array}$ & $\begin{array}{l}\text { Garcia-Murillo \& Annabi } \\
\text { (2002), Park \& Kim (2003), Smith } \\
\text { \& McKeen (2005) }\end{array}$ \\
\hline & $\begin{array}{l}\text { Customer } \\
\text { About } \\
\text { Knowledge }\end{array}$ & $\begin{array}{l}\text { Firm's comprehension on customer's background, desires } \\
\text { and preference on product characteristics }\end{array}$ & $\begin{array}{l}\text { Chen \& Su (2006), } \\
\text { Feng \& Tian (2005), } \\
\text { Park \& Kim (2003) }\end{array}$ \\
\hline \multirow{4}{*}{$\begin{array}{l}\text { CRM } \\
\text { Performance }\end{array}$} & $\begin{array}{l}\text { Financial } \\
\text { Perspective }\end{array}$ & $\begin{array}{l}\text { Measures such as net profit, net sales, reduced costs, market } \\
\text { share, customer share and cash flow }\end{array}$ & $\begin{array}{l}\text { Croteau and Li (2003), } \\
\text { Grabner-Kraeutera et al. (2007), } \\
\text { Kim et al. (2003), } \\
\text { Stefanou et al., (2003) }\end{array}$ \\
\hline & $\begin{array}{l}\text { Customer } \\
\text { Perspective }\end{array}$ & $\begin{array}{l}\text { Represents a modern approach for quality in enterprises and } \\
\text { organizations, and it serves the development of a truly } \\
\text { customer-focused management and culture. }\end{array}$ & $\begin{array}{l}\text { Croteau and Li (2003), } \\
\text { Grabner-Kraeutera et al. (2007), } \\
\text { Kim et al. (2003), } \\
\text { Stefanou et al., (2003) }\end{array}$ \\
\hline & $\begin{array}{l}\text { Internal } \\
\text { Process } \\
\text { Perspective }\end{array}$ & $\begin{array}{l}\text { Internal management approach that organizations undertake } \\
\text { to identify and develop in-depth knowledge about their } \\
\text { preferences }\end{array}$ & $\begin{array}{l}\text { Croteau and Li (2003), } \\
\text { Grabner-Kraeutera et al. (2007), } \\
\text { Kim et al. (2003), } \\
\text { Stefanou et al., (2003) }\end{array}$ \\
\hline & $\begin{array}{l}\text { Innovation } \\
\text { Perspective }\end{array}$ & $\begin{array}{l}\text { Management of relationships with customers is } \\
\text { fundamentally changing marketing and business models } \\
\text { and the marketing strategy models are transferring }\end{array}$ & $\begin{array}{l}\text { Croteau and Li (2003), } \\
\text { Grabner-Kraeutera et al. (2007), } \\
\text { Kim et al. (2003), } \\
\text { Stefanou et al., (2003) }\end{array}$ \\
\hline
\end{tabular}


Table 3. The Profiles of Respondents $(\mathrm{N}=201)$

\begin{tabular}{|c|c|c|}
\hline & Frequency & $\%$ \\
\hline \multicolumn{3}{|l|}{ MSC Status } \\
\hline $\begin{array}{l}\text { NO } \\
\text { YES }\end{array}$ & $\begin{array}{l}60 \\
141\end{array}$ & $\begin{array}{l}29.9 \\
70.1\end{array}$ \\
\hline \multicolumn{3}{|l|}{ Job Position } \\
\hline $\begin{array}{l}\text { Executive } \\
\text { Senior Executive } \\
\text { Manager } \\
\text { General Manager }\end{array}$ & $\begin{array}{l}29 \\
51 \\
91 \\
30\end{array}$ & $\begin{array}{l}14.4 \\
25.4 \\
45.3 \\
14.9 \\
\end{array}$ \\
\hline \multicolumn{3}{|l|}{ Department } \\
\hline $\begin{array}{l}\text { Marketing/Sales } \\
\text { Information Technology } \\
\text { Operation } \\
\text { Customer Service } \\
\text { Human Resource/Admin } \\
\text { Finance } \\
\text { Engineering } \\
\text { Research and Development } \\
\text { Others }\end{array}$ & $\begin{array}{l}38 \\
37 \\
19 \\
28 \\
28 \\
11 \\
14 \\
20 \\
6 \\
\end{array}$ & $\begin{array}{l}18.9 \\
18.4 \\
9.5 \\
13.9 \\
13.9 \\
5.5 \\
7.0 \\
10.0 \\
3.0 \\
\end{array}$ \\
\hline \multicolumn{3}{|l|}{ Nature of Business } \\
\hline $\begin{array}{l}\text { Business Process Outsourcing } \\
\text { Communication/Networking } \\
\text { Consultancy/Professional } \\
\text { Services } \\
\text { Creative Multimedia } \\
\text { Education/Training } \\
\text { Hardware Design } \\
\text { Internet Based Business } \\
\text { Network Security } \\
\text { Shared Services and } \\
\text { Outsourcing } \\
\text { Software Development } \\
\text { Support Services }\end{array}$ & $\begin{array}{l}8 \\
13 \\
27 \\
25 \\
10 \\
12 \\
22 \\
4 \\
21 \\
45 \\
14\end{array}$ & $\begin{array}{l}4.0 \\
6.5 \\
13.4 \\
12.4 \\
5.0 \\
6.0 \\
10.9 \\
2.0 \\
10.4 \\
22.4 \\
7.0\end{array}$ \\
\hline
\end{tabular}

Table 4. Descriptive Statistics of Variables

\begin{tabular}{|l|l|l|l|l|}
\hline Variable Name & $\begin{array}{l}\text { No of } \\
\text { Items }\end{array}$ & $\begin{array}{l}\text { Mean } \\
\text { (Std. Dev) }\end{array}$ & $\begin{array}{l}\text { Cronbach } \\
\text { Alpha }\end{array}$ & $\begin{array}{l}\text { Composite } \\
\text { Reliability }\end{array}$ \\
\hline Customer For Knowledge & $\mathbf{5}$ & $3.892(0.621)$ & 0.839 & 0.951 \\
\hline Customer From Knowledge & $\mathbf{6}$ & $3.619(0.891)$ & 0.934 & 0.978 \\
\hline Customer About Knowledge & $\mathbf{7}$ & $3.453(0.847)$ & 0.936 & 0.960 \\
\hline Financial Perspective & $\mathbf{6}$ & $4.032(0.517)$ & 0.843 & 0.952 \\
\hline Customer Perspective & $\mathbf{3}$ & $4.014(0.615)$ & 0.829 & 0.986 \\
\hline Internal Process Perspective & $\mathbf{8}$ & $4.039(0.569)$ & 0.918 & 0.916 \\
\hline Innovation Perspective & $\mathbf{5}$ & $4.199(0.567)$ & 0.890 & 0.948 \\
\hline Total items & $\mathbf{2 1}$ & \multicolumn{3}{|l|}{} \\
\hline
\end{tabular}


Table 5. Final Confirmatory Factor Analysis Results of Construct Variables

\begin{tabular}{|c|c|c|c|}
\hline Variable & Code & Attributes & Factor Loadings \\
\hline \multicolumn{4}{|c|}{ Customer Knowledge } \\
\hline $\begin{array}{l}\text { Knowledge for } \\
\text { Customer }\end{array}$ & $\begin{array}{l}\text { A2 } \\
\text { A3 } \\
\text { A4 }\end{array}$ & $\begin{array}{l}\text { Product Understanding } \\
\text { Informed Decision } \\
\text { Produce Information }\end{array}$ & $\begin{array}{l}0,716 \\
0,820 \\
0,810\end{array}$ \\
\hline $\begin{array}{l}\text { Knowledge from } \\
\text { Customer }\end{array}$ & $\begin{array}{l}\text { B1 } \\
\text { B3 } \\
\text { B6 }\end{array}$ & $\begin{array}{l}\text { Interactive Communication } \\
\text { Product and Service Satisfaction } \\
\text { Customer Feedback }\end{array}$ & $\begin{array}{l}0,884 \\
0,933 \\
0,848\end{array}$ \\
\hline $\begin{array}{l}\text { Knowledge about } \\
\text { Customer }\end{array}$ & $\begin{array}{l}\mathrm{C} 1 \\
\mathrm{C} 3 \\
\mathrm{C} 6\end{array}$ & $\begin{array}{l}\text { Customer Transactional Info } \\
\text { Regular Info Collection } \\
\text { Internal Customer Info }\end{array}$ & $\begin{array}{l}0,800 \\
0,813 \\
0,806 \\
\end{array}$ \\
\hline \multicolumn{4}{|c|}{ CRM Performance } \\
\hline $\begin{array}{l}\text { Financial } \\
\text { Perspective }\end{array}$ & $\begin{array}{l}\text { FIN1 } \\
\text { FIN2 } \\
\text { FIN3 } \\
\text { FIN4 }\end{array}$ & $\begin{array}{l}\text { Customer Loyalty } \\
\text { Customer Live Time Value } \\
\text { Customer Acquisition } \\
\text { Customer Retention Cost }\end{array}$ & $\begin{array}{l}0,772 \\
0,752 \\
0,755 \\
0,626\end{array}$ \\
\hline $\begin{array}{l}\text { Customer } \\
\text { Perspective }\end{array}$ & $\begin{array}{l}\text { CUST1 } \\
\text { CUST2 } \\
\text { CUST3 }\end{array}$ & $\begin{array}{l}\text { Customer Retention } \\
\text { Cross Sell Revenue } \\
\text { Customer Satisfaction }\end{array}$ & $\begin{array}{l}0,846 \\
0,757 \\
0,832\end{array}$ \\
\hline $\begin{array}{l}\text { Internal Process } \\
\text { Perspective }\end{array}$ & $\begin{array}{l}\text { INT4 } \\
\text { INT5 }\end{array}$ & $\begin{array}{l}\text { Targeting } \\
\text { Product Value }\end{array}$ & $\begin{array}{l}0,778 \\
0,733 \\
\end{array}$ \\
\hline $\begin{array}{l}\text { Innovation } \\
\text { Perspective }\end{array}$ & $\begin{array}{l}\text { INO1 } \\
\text { INO2 } \\
\text { INO5 }\end{array}$ & $\begin{array}{l}\text { Customer Insight } \\
\text { Product Development } \\
\text { Product Quality }\end{array}$ & $\begin{array}{l}0,777 \\
0,767 \\
0,761\end{array}$ \\
\hline Total Items & 21 & & \\
\hline
\end{tabular}

Table 6. Composite Reliability and Variance Extracted of Variables

\begin{tabular}{|c|c|c|c|c|c|}
\hline $\begin{array}{l}\text { Observed } \\
\text { Variables }\end{array}$ & Factor Loading & $\begin{array}{l}\text { Adj. } \\
\mathrm{R}^{2}\end{array}$ & Error variance & $\begin{array}{l}\text { Composite } \\
\text { reliability }\end{array}$ & $\begin{array}{l}\text { Variance } \\
\text { Extracted }\end{array}$ \\
\hline \multicolumn{6}{|c|}{ Knowledge for Customer } \\
\hline $\mathrm{A} 2$ & 0,716 & 0,513 & 0,077 & \multirow[t]{3}{*}{0,951} & \multirow[t]{3}{*}{0,868} \\
\hline A3 & 0,820 & 0,672 & 0,082 & & \\
\hline A4 & 0,810 & 0,656 & 0,122 & & \\
\hline \multicolumn{6}{|c|}{ Knowledge about Customer } \\
\hline B3 & 0,884 & 0,781 & 0,049 & \multirow[t]{3}{*}{0,978} & \multirow[t]{3}{*}{0,936} \\
\hline B4 & 0,933 & 0,870 & 0,060 & & \\
\hline B5 & 0,848 & 0,719 & 0,054 & & \\
\hline \multicolumn{6}{|c|}{ Knowledge from Customer } \\
\hline $\mathrm{C} 1$ & 0,800 & 0,640 & 0,077 & \multirow[t]{3}{*}{0,960} & \multirow[t]{3}{*}{0,889} \\
\hline $\mathrm{C} 3$ & 0,813 & 0,661 & 0,078 & & \\
\hline $\mathrm{C} 6$ & 0,806 & 0,650 & 0,088 & & \\
\hline \multicolumn{6}{|c|}{ Financial Perspective } \\
\hline FIN1 & 0,772 & 0,596 & 0,119 & \multirow[t]{4}{*}{0,952} & \multirow[t]{4}{*}{0,832} \\
\hline FIN2 & 0,752 & 0,566 & 0,096 & & \\
\hline FIN3 & 0,755 & 0,570 & 0,101 & & \\
\hline FIN4 & 0,626 & 0,392 & 0,114 & & \\
\hline \multicolumn{6}{|c|}{ Customer Perspective } \\
\hline CUST1 & 0,846 & 0,716 & 0.092 & \multirow[t]{3}{*}{0,986} & \multirow[t]{3}{*}{0,960} \\
\hline CUST2 & 0,757 & 0,573 & 0.085 & & \\
\hline CUST3 & 0,832 & 0,692 & 0,082 & & \\
\hline \multicolumn{6}{|c|}{ Internal Process Perspective } \\
\hline INT4 & 0,778 & 0,605 & 0,109 & \multirow[t]{2}{*}{0,916} & \multirow[t]{2}{*}{0,845} \\
\hline INT5 & 0,733 & 0,537 & 0,100 & & \\
\hline
\end{tabular}




\begin{tabular}{|c|c|c|c|c|c|}
\hline \multicolumn{6}{|l|}{ Innovation Perspective } \\
\hline INO1 & 0,777 & 0,604 & 0,101 & 0,948 & 0,859 \\
INO2 & 0,767 & 0,588 & 0,100 & & \\
INO5 & 0,761 & 0,579 & 0,089 & & \\
\hline
\end{tabular}

Table 7. Average Variance Extracted (AVE) Matrix of Variables

\begin{tabular}{|l|c|c|c|c|}
\hline Variable & $\mathbf{1}$ & $\mathbf{2}$ & $\mathbf{3}$ & $\mathbf{4}$ \\
\hline Customer Knowledge & & & & \\
\hline Knowledge for Customer (1) & 1.00 & - & - & - \\
\hline Knowledge from Customer (2) & 0.878 & 1.00 & - & - \\
\hline Knowledge about Customer (3) & 0.902 & 0.912 & 1.00 & - \\
\hline CRM Performance & & & & \\
\hline Financial Perspective (1) & 1.00 & - & - & - \\
\hline Customer Perspective (2) & 0.896 & 1.00 & - & - \\
\hline Internal Process Perspective (3) & 0.838 & 0.902 & 1.00 & - \\
\hline Innovation Perspective (4) & 0.845 & 0.909 & 0.852 & 1.00 \\
\hline
\end{tabular}

Table 8. Correlation \& Correlation squared Matrix

\begin{tabular}{|l|c|c|c|c|}
\hline Variable & $\mathbf{1}$ & $\mathbf{2}$ & $\mathbf{3}$ & $\mathbf{4}$ \\
\hline Customer Knowledge & & & & \\
\hline Knowledge for Customer (1) & 1.00 & - & - & - \\
\hline Knowledge from Customer (2) & $\begin{array}{c}0.780 \\
\mathbf{( 0 . 6 0 8 )}\end{array}$ & 1.00 & - & - \\
\hline Knowledge about Customer (3) & $\begin{array}{c}0.672 \\
\mathbf{( 0 . 4 5 1 )}\end{array}$ & $\begin{array}{c}0.777 \\
\mathbf{( 0 . 6 0 3 )}\end{array}$ & 1.00 & - \\
\hline CRM Performance & & & & \\
\hline Financial Perspective (1) & 1.00 & - & - & - \\
\hline Customer Perspective (2) & $\begin{array}{c}0.825 \\
\mathbf{( 0 . 6 8 0 )}\end{array}$ & 1.00 & - & - \\
\hline Internal Process Perspective (3) & $\begin{array}{c}0.819 \\
\mathbf{( 0 . 6 7 0 )}\end{array}$ & $\begin{array}{c}0.875 \\
\mathbf{( 0 . 7 6 5 )}\end{array}$ & 1.00 & - \\
\hline Innovation Perspective (4) & $\begin{array}{c}0.727 \\
\mathbf{( 0 . 5 2 8})\end{array}$ & $\begin{array}{c}0.813 \\
\mathbf{( 0 . 6 6 0 )}\end{array}$ & $\begin{array}{c}0.831 \\
\mathbf{( 0 . 6 9 0 )}\end{array}$ & 1.00 \\
\hline
\end{tabular}

** Correlation is significant at 0.01 level (2-tailed), values in brackets indicate correlation squared.

Table 9. Goodness of Fit Analysis -Comparison between Hypothesized, 2nd Order, Generated and Re-specified Model $(\mathrm{N}=201)$

\begin{tabular}{|l|c|c|c|c|c|}
\hline Finals Models & $\begin{array}{c}\text { Hypothesized } \\
\text { Model }\end{array}$ & $\begin{array}{c}\mathbf{2}^{\text {nd }} \text { Order of } \\
\text { Customer } \\
\text { Knowledge }\end{array}$ & $\begin{array}{c}\mathbf{2}^{\text {nd }} \text { Order of } \\
\text { CRM } \\
\text { Performance }\end{array}$ & $\begin{array}{c}\text { Generated } \\
\text { Model }\end{array}$ & $\begin{array}{c}\text { Re-specified } \\
\text { Model }\end{array}$ \\
\hline Items remain & 39 & 11 & 14 & 25 & 21 \\
\hline CMIN & 1378.068 & 50.428 & 91.708 & 373.352 & 209.775 \\
\hline Df & 694 & 42 & 73 & 267 & 179 \\
\hline CMIN/df & 1.986 & 1.201 & 1.256 & 1.398 & 1.172 \\
\hline P-value & 0.000 & 0.175 & 0.069 & 0.000 & 0.057 \\
\hline GFI & 0.752 & 0.956 & 0.940 & 0.874 & 0.909 \\
\hline RMSEA & 0.070 & 0.036 & 0.036 & 0.045 & 0.029 \\
\hline
\end{tabular}


Table 10. Results of Hypotheses Testing

\begin{tabular}{|c|c|c|c|c|c|c|c|}
\hline Нуро & Exogenous & Endogenous & $\begin{array}{c}\text { Std. } \\
\text { Estimate }\end{array}$ & $\begin{array}{l}\text { Std. } \\
\text { Error }\end{array}$ & CR & SMC & $\mathbf{P}$ \\
\hline $1 \mathbf{a}$ & $\begin{array}{l}\text { Knowledge } \\
\text { For Customer }\end{array}$ & $\begin{array}{l}\text { Customer } \\
\text { Knowledge }\end{array}$ & 0.828 & 0.074 & 9.266 & 0.685 & 0.000 \\
\hline $1 b$ & $\begin{array}{l}\text { Knowledge } \\
\text { From } \\
\text { Customer }\end{array}$ & $\begin{array}{l}\text { Customer } \\
\text { Knowledge }\end{array}$ & 0.961 & 0.160 & 9.006 & 0.923 & 0.000 \\
\hline $1 \mathrm{c}$ & $\begin{array}{l}\text { Knowledge } \\
\text { About } \\
\text { Customer }\end{array}$ & $\begin{array}{l}\text { Customer } \\
\text { Knowledge }\end{array}$ & 0.800 & 0.157 & 9.266 & 0.640 & 0.000 \\
\hline $2 \mathbf{a}$ & $\begin{array}{l}\text { Financial } \\
\text { Perspective }\end{array}$ & $\begin{array}{l}\text { CRM } \\
\text { Performance }\end{array}$ & 0.864 & 0.080 & 9.568 & 0.746 & 0.000 \\
\hline $2 b$ & $\begin{array}{l}\text { Customer } \\
\text { Perspective }\end{array}$ & $\begin{array}{l}\text { CRM } \\
\text { Performance }\end{array}$ & 0.905 & 0.125 & 9.624 & 0.819 & 0.000 \\
\hline $2 c$ & $\begin{array}{l}\text { Internal } \\
\text { Process } \\
\text { Perspective }\end{array}$ & $\begin{array}{l}\text { CRM } \\
\text { Performance }\end{array}$ & 0.940 & 0.093 & 10.279 & 0.883 & 0.000 \\
\hline $2 d$ & $\begin{array}{l}\text { Innovation } \\
\text { Perspective }\end{array}$ & $\begin{array}{l}\text { CRM } \\
\text { Performance }\end{array}$ & 0.869 & 0.086 & 9.624 & 0.755 & 0.000 \\
\hline 3 & $\begin{array}{l}\text { Customer } \\
\text { Knowledge }\end{array}$ & $\begin{array}{l}\text { CRM } \\
\text { Performance }\end{array}$ & 0.584 & 0.091 & 6.495 & 0.341 & 0.000 \\
\hline
\end{tabular}

Hypothesized Model

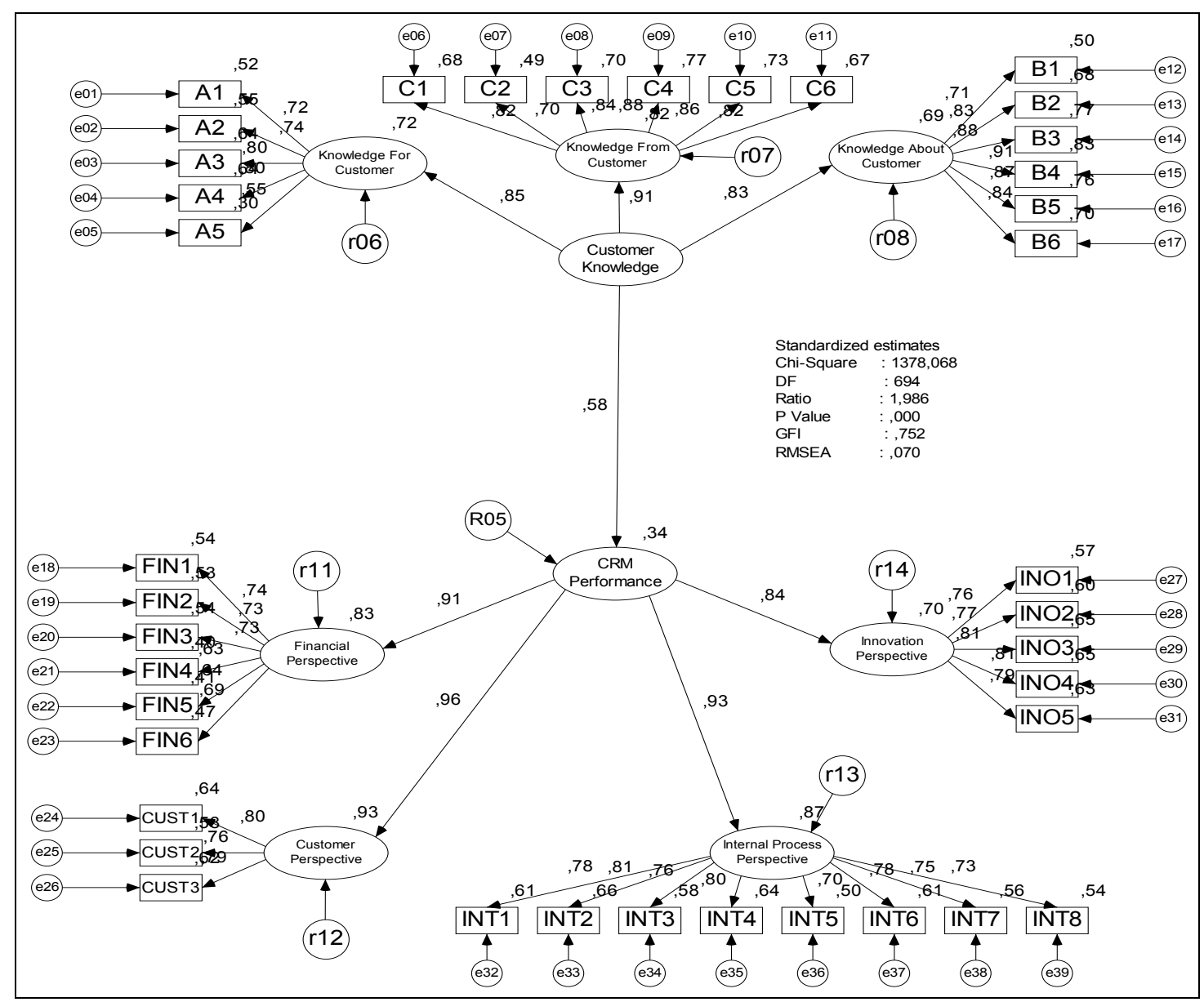

Figure 1. 
$2^{\text {nd }}$ Order Analysis of Customer Knowledge

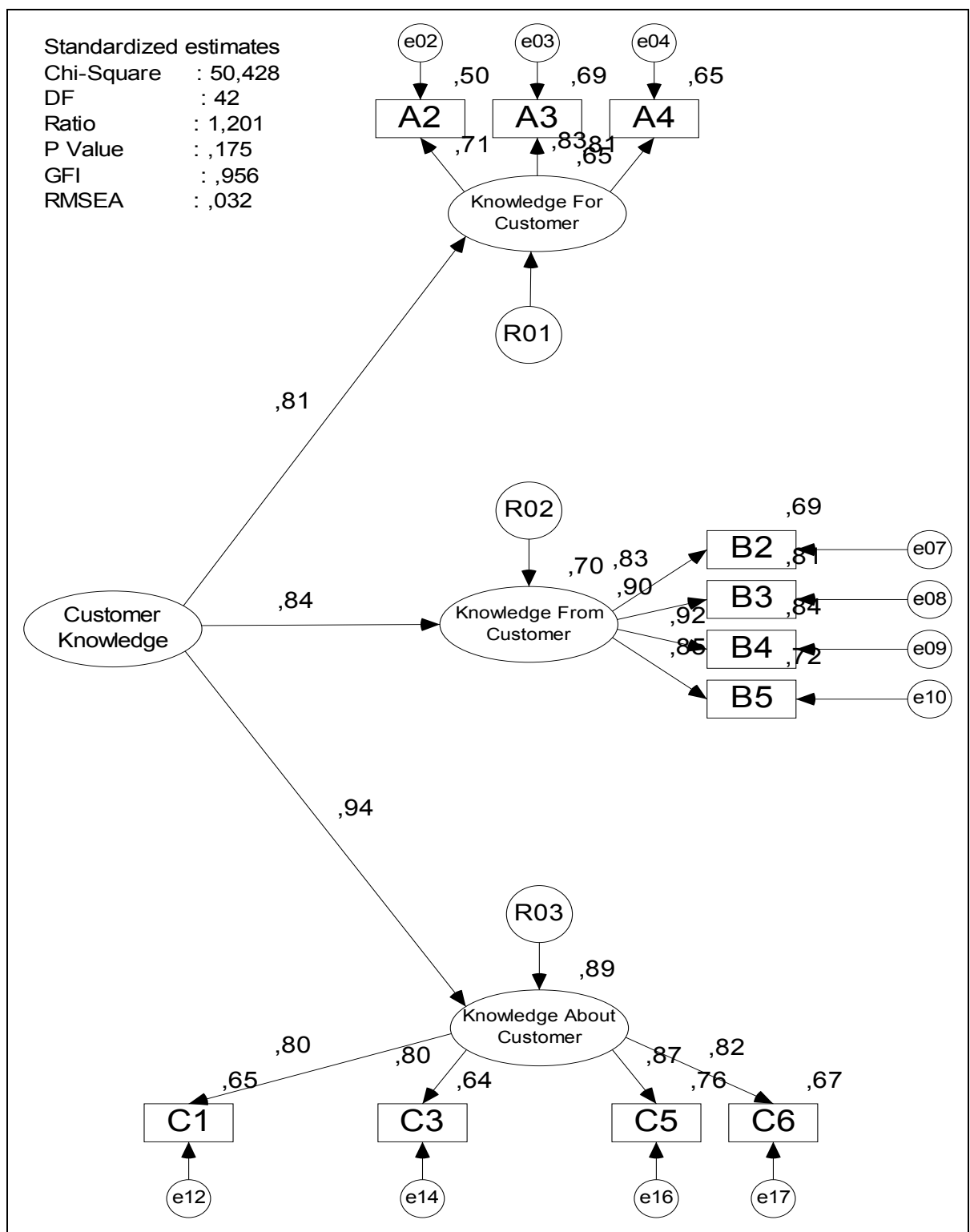

Figure 2. 
$2^{\text {nd }}$ Order Analysis of CRM Performance Generated Model

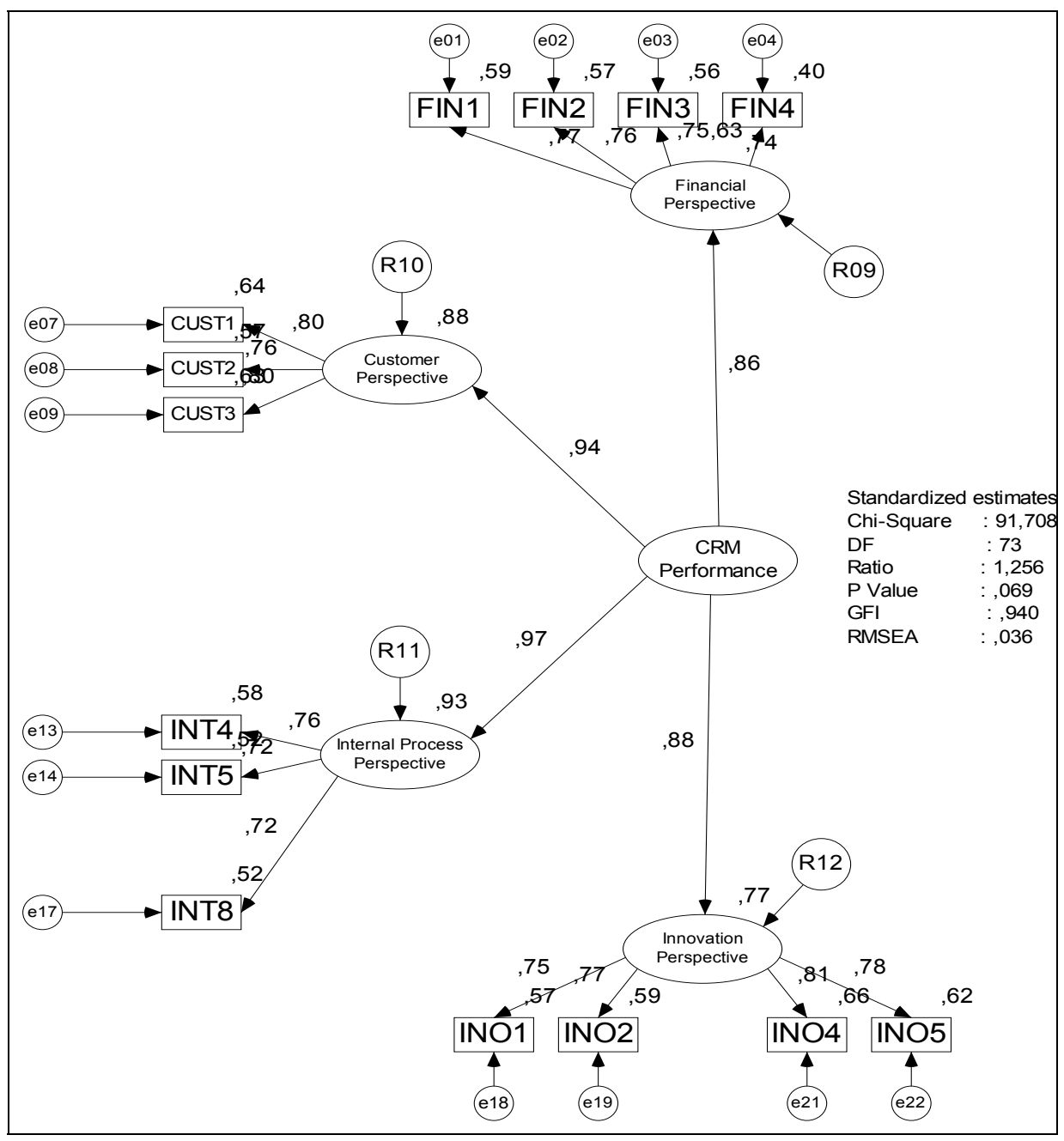

Figure 3. 


\section{Generated Model}

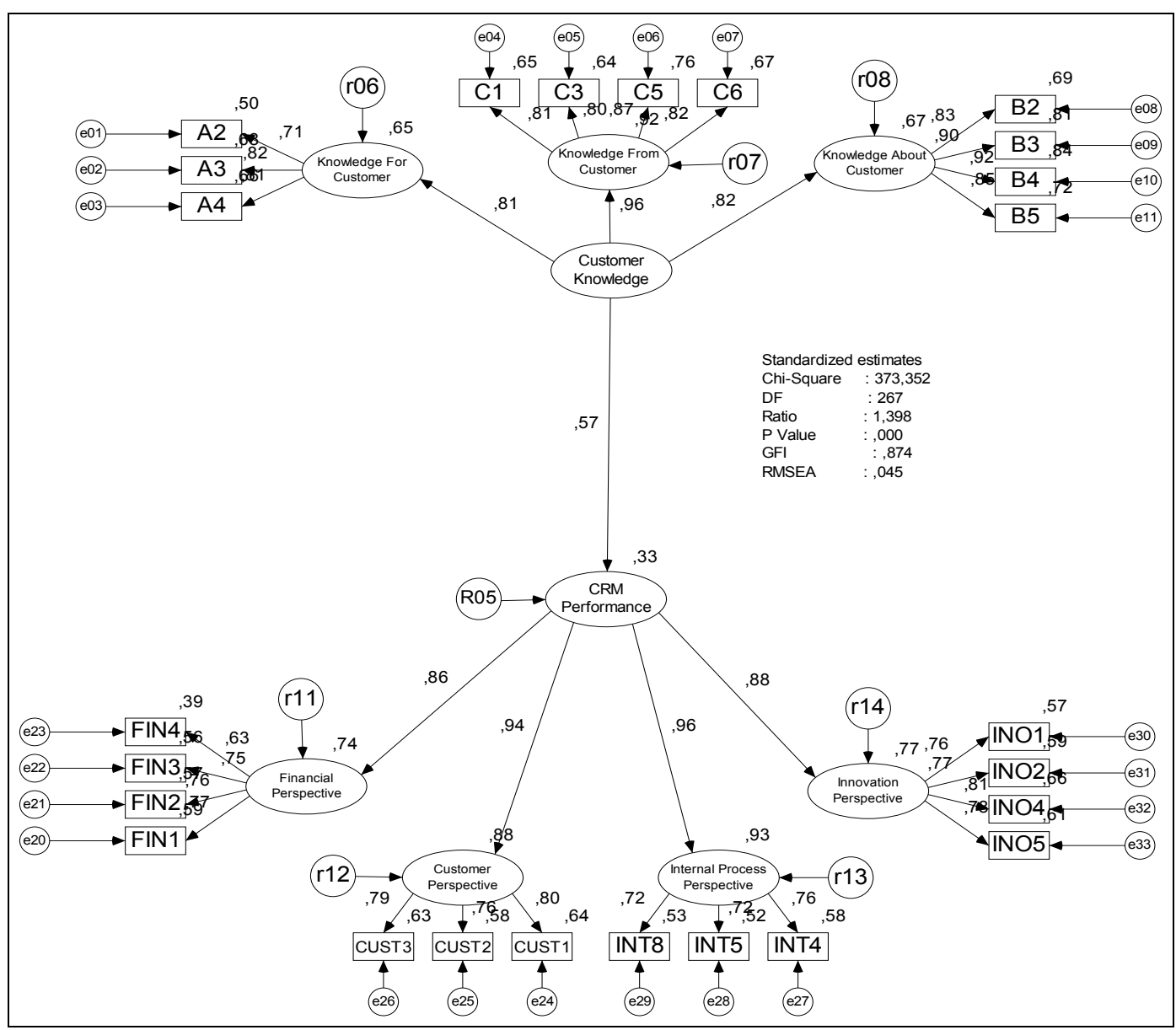

Figure 4. 


\section{Re-specified Model}

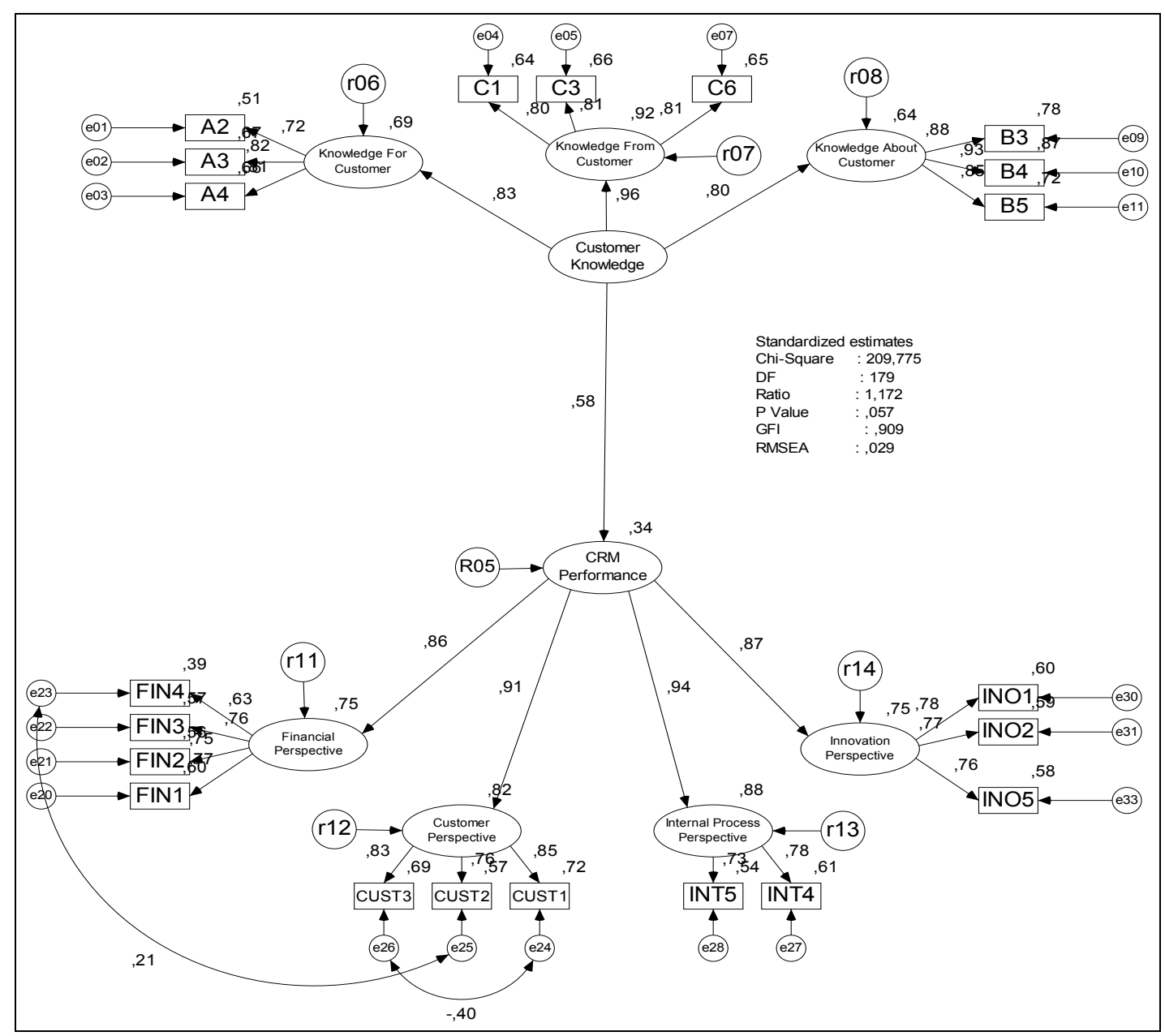

Figure 5. 